\title{
Persistent changes in forest vegetation and seed bank 1,600 years after human occupation
}

\author{
Jan Plue - Martin Hermy - Kris Verheyen • \\ Patrice Thuillier $\cdot$ Robert Saguez $\cdot$ Guillaume Decocq
}

Received: 17 October 2007 / Accepted: 19 April 2008/Published online: 21 May 2008

(C) Springer Science+Business Media B.V. 2008

\begin{abstract}
Past land use is an important factor determining vegetation in temperate deciduous forests. Little is known about the long-term persistence of these impacts on vegetation but especially on the seed bank. This study assessed whether soil characteristics remain altered 1,600 years after human occupation and if this yielded persistent differences in forest plant communities and their seed bank in particular. Compiègne forest is located in northernFrance and has a history of continuous forest cover since the end of Roman times. Twenty-four GalloRoman and 24 unoccupied sites were sampled and data were analysed using paired sample tests to investigate whether soil, vegetation and seed bank still differed significantly. The soil was persistently altered on the Gallo-Roman sites resulting in elevated phosphorus levels and $\mathrm{pH}$ (dependent on initial soil conditions) which translated into increased vegetation and seed bank species richness. Though spatially
\end{abstract}

J. Plue $(\bowtie) \cdot$ M. Hermy

Division for Forest, Nature and Landscape Research, Katholieke Universiteit Leuven, Celestijnenlaan 200E, 3001 Leuven, Belgium

e-mail: jan.plue@ees.kuleuven.be

\section{K. Verheyen}

Laboratory of Forestry, Ghent University,

Geraardsbergsesteenweg 267, 9090 Ghent, Belgium

P. Thuillier $\cdot$ R. Saguez $\cdot$ G. Decocq

Department of Botany, University of Picardie Jules Verne,

Rue des Louvels 1, Amiens Cedex 80037, France isolated, Gallo-Roman sites supported both a homogenized vegetation and seed bank. Vegetation differences were not the only driver behind seed bank differences. Similarity between vegetation and seed bank was low and the possibility existed that agricultural ruderals were introduced via the former land use. Ancient human occupation leaves a persistent trace on forest soil, vegetation and seed bank and appears to do so at least 1,600 years after the former occupation. The geochemical alterations created an entirely different habitat causing not only vegetation but also the seed bank to have altered and homogenized composition and characteristics. Seed bank differences likely persisted by the traditional forest management and altered forest environment.

Keywords Anthropogenic legacies . Biodiversity · France · Gallo-Roman occupation · Historical ecology · Land use history · Seed bank $\cdot$ Soil $\cdot$ Vegetation

\section{Introduction}

Forest cover in Europe has at times been less stable as might be imagined. Throughout the temperate zone of Northwest-Europe and North-America, many forests have known a human occupation or land use at some point in their history. As forests are slowly recovering ecosystems (e.g. Schulte et al. 2007) and display 
substantial time lags between impacts and effects, the need to integrate history into forest ecology is further emphasized (Bürgi and Gimmi 2007).

The effects of former human occupation or agricultural land use in forests may be visible both in the soil and vegetation. It is well documented that agricultural land use modifies geochemical soil properties and that these alterations may last for centuries (e.g. Sandor et al. 1990; Sandor and Eash 1995; Verheyen et al. 1999; Dupouey et al. 2002; Dambrine et al. 2007). However, other studies documented a significant recovery of soil characteristics on former agricultural lands (e.g. Graae et al. 2003; Flinn et al. 2005). Nonetheless, the long-term alteration of geochemical conditions on the one hand (e.g. Verheyen et al. 1999; Dupouey et al. 2002; Dambrine et al. 2007) and particularly the dispersal limitation of forest species on the other hand (e.g. Verheyen and Hermy 2001; Flinn and Vellend 2005) resulted in altered plant communities (e.g. Peterken and Game 1984; Bellemare et al. 2002) containing few typical, ancient forest plant species (e.g. Peterken and Game 1984; Hermy et al. 1999). In addition, Vellend et al. (2007), in correspondence to earlier results of Harrelson and Matlack (2006), proved that the land use induced soil changes combined with dispersal limitation homogenized these recent forest plant communities and weakened species-environment relationships.

In the literature, the question as to how long human impact on soil and vegetation remains detectable, has received little attention (but see Dupouey et al. 2002; Decocq et al. 2002; Vanwalleghem et al. 2004; Dambrine et al. 2007), with most research focusing on-in forest terms-short timeframes of about 50-150 years (e.g. Koerner et al. 1997). Furthermore, little is known on the effects of former land use on persistent seed banks of forests (for a review see Bossuyt and Hermy 2001; Bossuyt et al. 2002). It may even seem unnecessary to investigate long-term impacts, something that to our knowledge has never been done before, as Bossuyt et al. (2002) reported that seed banks of recent forest resemble those of ancient forest after only 50-100 years. However, knowing that type, intensity and duration of the past land use can differ greatly, it may be expected that the magnitude and persistence of these effects also differ (cf. Koerner et al. 1997; Verheyen et al. 1999; Compton and Boone 2000;
Bellemare et al. 2002; Flinn et al. 2005). The Compiègne forest complex near Paris, Northern France offers a unusual opportunity to investigate the longterm vegetation and seed bank impacts of ancient intensive land use, as it contains many sites of former Gallo-Roman occupation (Doyen et al. 2004). These Gallo-Roman sites are well preserved in this large forest, which has probably never known another human occupation or agricultural land use since Roman times. So far, in France alone more than 9,400 similar sites, currently under forest, have been identified to have had a prior Gallo-Roman land use (Maussion 2003). This is thus not only an important issue for France, but also for other European countries which were formerly occupied by the Romans as they equally have Gallo-Roman sites under their forests (cf. Pounds 1973; Vanwalleghem et al. 2004).

In this study we took advantage of the unusual set of conditions occurring in the Compiègne forest to test the hypothesis that the 1,600-years old GalloRoman occupation had persistently altered the geochemical characteristics of the soil. Whether and how these altered soil conditions were reflected in both present vegetation and seed bank was tested as well. Thereby it was hypothesized that the vegetation of formerly occupied sites will exhibit an increased $\alpha$-biodiversity and that both vegetation and seed bank composition are more homogenized on the occupied sites, based on Vellend et al. (2007). The hypothesis was tested that the Gallo-Roman occupation had altered the seed bank characteristics by the introduction of several ruderal species into the seed bank. Finally, we tested whether an interaction exists between the modifications in soil, vegetation and seed bank characteristics and initial soil conditions as we hypothesized that the past land use effect should be more pronounced on previously acid soils.

\section{Methods}

Study area

The forest of Compiègne, located in northern France $\left(49^{\circ} 22^{\prime} \mathrm{N} ; 2^{\circ} 54^{\prime} \mathrm{E}\right.$; $32-148 \mathrm{~m}$ altitude) is predominantly an oak-beech forest, covering a total area of $144 \mathrm{~km}^{2}$ (Fig. 1). It is situated in a large plain (average $50 \mathrm{~m}$ a.s.1.) bordered by the rivers Aisne and Oise and surrounded by calcareous hills and plateaus. 
Fig. 1 Location of Compiègne forest in France (Picardie, Departement Oise) and sampled GalloRoman and unoccupied sites in the forest of Compiègne

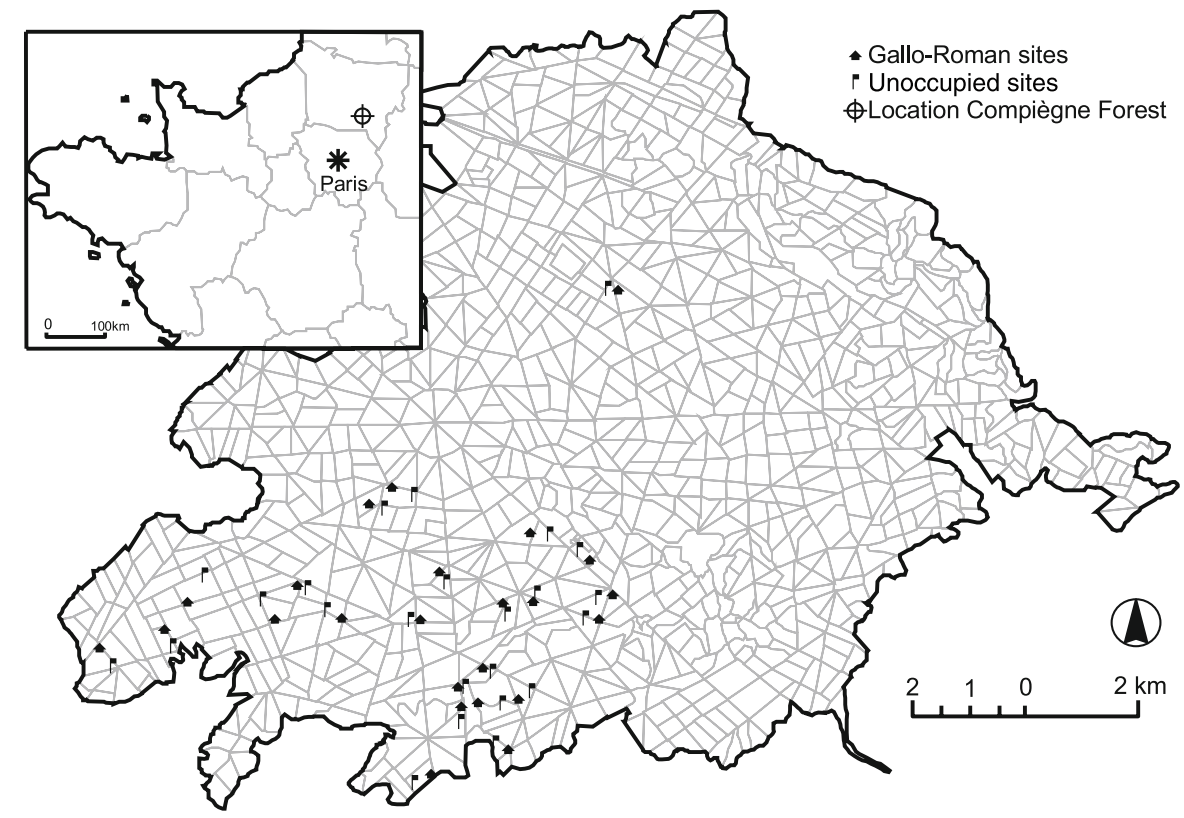

The climate is oceanic with a mean annual temperature of $10.3^{\circ} \mathrm{C}$ and annual rainfall of $677 \mathrm{~mm}$, with a small positive hydrological balance of $15.8 \mathrm{~mm}$. The geological substrate mainly consists of Palaeogeneous sands (ca. 60\% of total area) and Cretaceous chalk (ca. 20\%), locally covered by Quaternary loess and alluvial deposits. Soils are very diverse (FAOclassification: Cambisols, Podzols, Gleysols, Luvisols, Alisols, rendzinic Leptosols and RegosolsFluvisols).

Romans settled in the Compiègne area during the 1st century AC. Through archaeological surveys, a total of 171 Gallo-Roman buildings were discovered within the perimeter of the contemporary forest (Thuillier 2004), including vici (small villages), villae (large farms surrounded by agricultural land, barns and houses for labourers) and guest-houses (small country houses). Most of these are distributed towards the south-western part of the forest, which is close to the Oise river and the former SenlisSoissons Roman road. They usually consisted of $60 \mathrm{~cm}$-high foundations made of calcareous stones, supporting a wooden frame covered by cob walls and a tile roof. Each isolated site consisted of a built area (200-1,000 $\mathrm{m}^{2}$ ), associated with land used for agricultural activities within an estimated radius of ca. $200 \mathrm{~m}$. All these sites were abandoned at the end of the 4th century AC under unclear circumstances (possibly the Franc invasion, arable land exhaustion and/or inclusion of the area in the Royal domain) and the whole area became entirely afforested. The first mention of the Compiègne forest (Silva Cotia) in archival sources dates from 561 AC (Histoire des Francs by Grégoire de Tours, 4th book). The area has remained continuously afforested until now, but was not undisturbed. Several war-related local clearcuts occurred during both Medieval and modern times. The first exploitations seem to have already occurred during the Dark Ages (500-800 A.C.). This pattern of initially irregular exploitation gradually shifted to annual fellings of standard areas from the 17th century onwards and increased to about $2.5 \mathrm{~km}^{2}$ year ${ }^{-1}$ during the 18 th century. This led to the introduction of some major forest management types: high forest and coppice, shifting to high forest (sensu Peterken 1996) and coppice with standards by the end of the 19th century. The forest is currently managed as a high forest of common beech (Fagus sylvatica), oaks (Quercus robur, Q. petraea) and Scots pine (Pinus sylvestris) (plant nomenclature follows Lambinon et al. 1998). The silvicultural cycle lasts 180-years for Quercus robur and Q. petraea, 110 years for Fagus sylvatica and 100 years for Pinus sylvestris, and always starts by a clearcut (order of magnitude $0.1-0.2 \mathrm{~km}^{2}$ ). During this time interval, thinnings are conducted every 4-10 years (O.N.F. 1995). Natural disturbances mainly consist of decennial wind throws. 
Sampling sites

On the basis of maps representing archaeological findings from the Gallo-Roman period, 24 GalloRoman sites corresponding to former isolated residences (i.e. villa or other inhabited buildings, vici being excluded since non-isolated) were selected at random (Fig. 1). Then, to control for environmental variation, each archaeological site was paired to an unoccupied site in the immediate vicinity $(200 \mathrm{~m}$ on average). Based on soil maps, these sites were selected to have similar soil types (i.e. the soil under the layer of Gallo-Roman material and the soil on the unoccupied sites) and topographical conditions (i.e. in the plain between 30 and $60 \mathrm{~m}$ ). Furthermore, paired sites had similar forest canopy conditions, based on dominant tree species and forest quality maps (Fr. stations forestières). This control for pre-existing environmental variation in relatively heterogeneous forests like Compiègne forest facilitates isolation of the direct effects of land use (cf. Flinn and Vellend 2005). Archaeological sites were easy to find in the field, as a dense understorey vegetation proved to be an indication of a reclaimed building. On closer inspection, the soils contained stone fragments, pieces of chalk and shards of roof tiles (tegulae) scattered in the upper soil layers. Several sites were raised $( \pm 20-30 \mathrm{~cm})$ partly due to stone fragment accumulation. Sometimes, fruit trees, such as Malus sylvestris and Mespilus germanica appeared in the woody forest strata on or in the immediate vicinity of a Gallo-Roman site. Unoccupied sites had no stone fragments and showed no additional elevation to their surroundings. The distance criterion of $200 \mathrm{~m}$ applied in this study is supported by Dupouey et al. (2002) and Dambrine et al. (2007) who found little proof of agriculture beyond that distance.

\section{Data collection}

Within each site, a plot of $800 \mathrm{~m}^{2}$ was selected and the percentage cover of each plant species was estimated during June and July of 2002 following the BraunBlanquet method (Kent and Coker 1992). After removal of the litter layer, five random soil cores were sampled at a maximum depth of $15 \mathrm{~cm}$ per plot, and subsequently pooled and mixed. They were analysed for organic carbon (OC; Anne 1945), $\mathrm{pH}(\mathrm{KCl})$, total N (Kjeldahl method), plant-available P (Olsen method), total P (Bray and Kurtz 1945) and active Ca (Loeppert and Suarez 1996). All analyses were performed as described in Aubert (1978) and Pansu and Ghauteyrou (2003). In mid-August 2004, 25 supplementary random core samples per plot were taken with a small auger $(\varnothing 26 \mathrm{~mm})$ to a depth of $20 \mathrm{~cm}$ after removal of the litter layer, for seed bank analysis (cf. Bigwood and Inouye 1988). All soil samples on the Gallo-Roman sites were collected only on the building sites. Each individual soil core was divided into two depths (0-10 and $10-20 \mathrm{~cm}$ ) and all 25 soil cores were mixed per depth class. They were stored in paper bags and kept cool and dark until further processing. The concentration method proposed by Ter Heerdt et al. (1996) was used to analyse the mixed soil samples. The concentrated samples, spread out over steam-sterilized compost, were allowed to germinate under a $16 \mathrm{~h}$ day, $8 \mathrm{~h}$-night regime, with day temperatures ranging between 25 and $30^{\circ} \mathrm{C}$. They were kept moist through capillary rise from an underlying layer of clayexpanded granules which was watered $2-3$ times a week and fertilized once every 3 weeks. The germination period (33 weeks) was interrupted after 20 weeks by a cold stratification period $\left(2^{\circ} \mathrm{C}\right.$ for 5 weeks) and a consecutive superficial perturbation of the soil in the containers. All identified seedlings were counted and removed, whilst unidentified seedlings were transplanted and brought to flower for later identification. As some Betula and Calluna vulgaris seedlings were found in the control containers containing only sterilized compost, these two taxa were not incorporated in further data analyses.

\section{Data analysis}

Plant species richness of vegetation [herbaceous, shrub $(<1.5 \mathrm{~m})$, coppice $(1.5-8 \mathrm{~m})$ and canopy layer $(>8 \mathrm{~m})$ ], seed bank and total community were computed as $\alpha$-diversity measures. Beta-diversity for both vegetation and seed bank among plots of a site type (intra-type $\beta$-diversity) was calculated using the measure of Raup and Crick (1979) following the procedure of Vellend et al. (2007). However, the average plot $\beta$-diversity was computed within one site type rather than the overall average, as community composition between site types is so different that inter-type dissimilarities would otherwise obscure results. The Raup and Crick dissimilarity measure (1979) was also calculated to compute the discrepancy between vegetation and seed bank per plot. 
The original Braun-Blanquet vegetation data were transformed to cover percentages, while raw seed bank data were log-transformed. Subsequently, they were used to calculate mean Ellenberg indicator values (EIVs) for Light (L), Moisture (F), Soil acidity (R) and Soil fertility (N) (Ellenberg et al. 1992); CSR signature (Hunt et al. 2004) and the Shannon-Wiener diversity index for the vegetation as well as the seed bank. Seed bank variables calculated based on abundance data omitted Juncus effusus (further referred as $\mathrm{Je}$ ) - a common procedure among seed bank researchers (e.g. Bossuyt et al. 2002)-because of the bias this species would otherwise cause (cf. seed density differences; Table 2). Forest light conditions were simulated by dividing woody forest species into a group of deep shade-casting versus light shade-casting species (see Appendix S1 in Supplementary Materials; Ellenberg 1996). For each group, the transformed cover (Van der Maarel 1979) was summed per stratum per plot. Furthermore, total cover of the entire forest canopy, arborescent stratum and coppice stratum was calculated per plot.

All variables, including the chemical soil variables and seed bank densities, were tested for differences between Gallo-Roman and unoccupied sites using the Wilcoxon signed ranks test (Siegel and Castellan 1988). Differences in species composition were tested by applying a McNemar test (Siegel and Castellan 1988) on the presence/absence data of vegetation and seed bank. Interaction between soil type and past land use effect was examined to control for the differences in soil types between couples of paired sites (cf. Table 1; range $\mathrm{pH}$ unoccupied sites). Therefore, spearman rank correlation between unoccupied site $\mathrm{pH}$ as a measure for natural soil variability and withinpair differences (occupied-unoccupied) in soil $\mathrm{pH}$, total $\mathrm{P}$, vegetation and seed bank $\alpha$-diversity and seed densities were calculated. All statistical analyses were performed in SPSS 12.0 for Windows (SPSS 2003).

\section{Results}

Environmental conditions

Soil $\mathrm{pH}$, plant-available and total soil phosphorus content were significantly higher on Gallo-Roman sites, with $\mathrm{pH}$ being more than one unit higher (Table 1). Differences in OC, active calcium content and plant-available $\mathrm{P} /$ total $\mathrm{P}$ ratio between site types were not significant. The mean vegetation EIV for soil acidity $(\mathrm{R})$, fertility $(\mathrm{N})$ and moisture $(\mathrm{F})$ were also significantly higher on Gallo-Roman sites (Table 2).

Total cover of light shade-casting species was significantly higher on Gallo-Roman for both the arborescent (7 vs. $5, \mathrm{Z}=-3.26 ; P \leq 0.001$ ) and coppice strata ( 5 vs. $0, \mathrm{Z}=-3.27 ; P \leq 0.001$ ). There was no difference in the cover of deep shade-casting species in both strata between site types. These results suggest different light conditions between site types. However, as total cover of the two strata was significantly greater on Gallo-Roman sites, this probably counteracted the effect of the higher cover of light-shade casting species. This hypothesis is

Table 1 Geochemical soil characteristics on Gallo-Roman and unoccupied sites: results of the Wilcoxon signed ranks test

\begin{tabular}{|c|c|c|c|c|c|c|c|c|}
\hline & \multicolumn{3}{|c|}{ Gallo-Roman $(n=24)$} & \multicolumn{3}{|c|}{ Unoccupied $(n=24)$} & \multirow[t]{2}{*}{$Z$} & \multirow[t]{2}{*}{ Sign. } \\
\hline & Median & Range & Coefficient of variation & Median & Range & Coefficient of variation & & \\
\hline N-tot $(\mathrm{g} / \mathrm{kg})$ & 2.14 & 3.06 & 0.35 & 1.51 & 4.12 & 0.93 & -1.71 & n.s. \\
\hline P-tot $(\mathrm{g} / \mathrm{kg})$ & 0.67 & 1.73 & 0.53 & 0.37 & 1.81 & 0.79 & -4.14 & $* * *$ \\
\hline P-ass $(\mathrm{g} / \mathrm{kg})$ & 0.04 & 0.12 & 0.49 & 0.04 & 0.12 & 0.67 & -1.99 & $*$ \\
\hline $\mathrm{pH} \mathrm{KCl}$ & 6.00 & 3.73 & 0.16 & 3.90 & 4.33 & 0.28 & -3.92 & $* * *$ \\
\hline $\mathrm{pH} \mathrm{H}_{2} \mathrm{O}$ & 6.80 & 4.09 & 0.14 & 5.15 & 4.26 & 0.22 & -3.89 & $* * *$ \\
\hline $\mathrm{OC}(\mathrm{g} / \mathrm{kg})$ & 34.33 & 73.94 & 0.51 & 27.04 & 79.68 & 0.58 & -1.23 & n.s. \\
\hline P-ass/P-tot & 0.07 & 0.30 & 0.82 & 0.07 & 0.52 & 1.03 & -1.42 & n.s. \\
\hline $\mathrm{Ca}(\mathrm{g} / \mathrm{kg})$ & 1.05 & 2.15 & 0.43 & 0.88 & 1.58 & 0.46 & -1.64 & n.s. \\
\hline
\end{tabular}

* $0.01<P \leq 0.05$; ** $0.001<P \leq 0.01$; *** $P \leq 0.001$; n.s., not significant

Sign., level of significance; N-tot, total soil nitrogen content; P-tot, total soil phosphorus content; P-ass, total plant-available soil phosphorus content; $\mathrm{Ca}$, active soil calcium content; OC, organic carbon content 
Table 2 Differences in vegetation (percentage cover) and 0-20 cm seed bank characteristics (log-transformed) between GalloRoman and unoccupied sites as observed using a Wilcoxon signed ranks test

\begin{tabular}{|c|c|c|c|c|c|c|c|c|}
\hline & \multicolumn{4}{|l|}{ Vegetation } & \multicolumn{4}{|l|}{ Seed bank } \\
\hline & Median $(n=24)$ & UnOc. & $Z$ & Sign. & Median $(n=24)$ & UnOc. & $Z$ & Sign. \\
\hline \multicolumn{9}{|l|}{ Species richness } \\
\hline Herbaceous stratum & 30.50 & 18.50 & -4.20 & $* * *$ & & & & \\
\hline Tree stratum & 5.00 & 3.50 & -2.91 & $* *$ & & & & \\
\hline Coppice stratum & 6.00 & 2.50 & -3.54 & $* * *$ & & & & \\
\hline Shrub stratum & 6.00 & 0.00 & -3.73 & $* * *$ & & & & \\
\hline Vegetation & 38.00 & 22.50 & -4.28 & $* * *$ & & & & \\
\hline Species richness ${ }^{\mathrm{a}}$ & & & & & 6.00 & 4.00 & -2.62 & $* *$ \\
\hline Seed density (number $\mathrm{m}^{-2}$ ) $^{\mathrm{c}}$ & & & & & 2277.78 & 8777.78 & -3.63 & $* * *$ \\
\hline Seed density (number $\mathrm{m}^{-2}$ ) $^{\mathrm{d}}$ & & & & & 1500.00 & 333.33 & -2.82 & $* *$ \\
\hline$J e$ seed density (number $\mathrm{m}^{-2}$ ) & & & & & 0.00 & 7388.89 & -4.16 & $* * *$ \\
\hline Shannon-Wiener index ${ }^{b}$ & 1.48 & 1.27 & -3.74 & $* * *$ & 0.68 & 0.47 & -2.66 & $* *$ \\
\hline $\mathrm{C}^{\mathrm{b}}$ & 0.43 & 0.37 & -2.73 & $* *$ & 0.49 & 0.33 & -2.42 & $*$ \\
\hline$S^{b}$ & 0.36 & 0.44 & -4.20 & $* * *$ & 0.19 & 0.28 & -3.10 & $* *$ \\
\hline $\mathrm{R}^{\mathrm{b}}$ & 0.21 & 0.19 & -2.41 & $*$ & 0.29 & 0.36 & -0.37 & n.s. \\
\hline EIV for light & 4.04 & 3.86 & -1.10 & n.s. & & & & \\
\hline EIV for moisture & 5.46 & 5.15 & -3.69 & $* * *$ & & & & \\
\hline EIV for soil acidity & 6.56 & 6.14 & -3.44 & $* * *$ & & & & \\
\hline EIV for soil fertility & 6.09 & 5.66 & -4.11 & $* * *$ & & & & \\
\hline$\beta_{\mathrm{rc}}^{\mathrm{a}}$ & 0.17 & 0.31 & -3.06 & $* *$ & 0.53 & 0.76 & -3.26 & $* * *$ \\
\hline
\end{tabular}

* $0.01<P \leq 0.05$; ** $0.001<P \leq 0.01$; *** $P \leq 0.001$; n.s. not significant

a Juncus effusus was included in the analysis as the variable was calculated on basis of presence/absence data

b Juncus effusus was excluded from the analysis as the variable was calculated on basis of abundance data

c Seed density expressed with Juncus effusus

d Seed density without Juncus effusus

UnOc., unoccupied; Je, Juncus effusus; Sign., level of significance; C, competitive character; S, stress-tolerant character; R, ruderal character; EIV, mean Ellenberg value; $\beta_{\text {rc }}$, Raup and Crick intra-type $\beta$-diversity

supported by the equal EIV for light of the vegetation, which indicate that both site types have similar light conditions on the forest floor (Table 2).

\section{Vegetation}

The Gallo-Roman sites together contained 126 vascular plant species with an average of $37.13( \pm 1.44)$ species per plot against only 98 species with an average of $23.17( \pm 1.39)$ species per plot on the unoccupied sites. Over all sites, 134 species were found. All forest strata contained significantly more species on the Gallo-Roman sites (Table 2). This also holds for the Shannon-Wiener index. Significant differences were obtained for the various plant strategy types. The vegetation on Gallo-Roman sites had a significantly more competitive and ruderal character, while the unoccupied site vegetation was more stress-tolerant. Intra-type $\beta$-diversity was significantly lower on the Gallo-Roman sites. The floristic analysis revealed 20 herbaceous species with a preferential occurrence on one of the site types, 19 species were significantly more frequent on GalloRoman sites (e.g. Brachypodium sylvaticum, Circaea lutetiana, Euphorbia amygdaloides, Glechoma hederacea, Urtica dioica) against only one significant preferential occurrence (Carex pilulifera) on the unoccupied sites (Table 3). 
Table 3 Plant frequencies on Gallo-Roman and unoccupied sites

\begin{tabular}{|c|c|c|c|c|c|c|c|}
\hline Plant species & $\begin{array}{l}\text { Gallo-Roman } \\
(n=24)\end{array}$ & Unoccupied & Sign. & Plant species & $\begin{array}{l}\text { Gallo-Roman } \\
(n=24)\end{array}$ & Unoccupied & Sign. \\
\hline Alliaria petiolata & 13 & 3 & $* *$ & Glechoma hederacea ${ }^{\mathrm{sb}}$ & 7 & 1 & $*$ \\
\hline Arum maculatum & 13 & 5 & $* *$ & 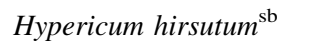 & 8 & 2 & n.s. \\
\hline Atropa bella-donna ${ }^{\mathrm{sb}}$ & 4 & 0 & n.s. & Hypericum perforatum $^{\mathrm{sb}}$ & 9 & 2 & n.s. \\
\hline Brachypodium sylvaticum & 24 & 14 & $* *$ & Juncus effusus ${ }^{\mathrm{sb}}$ & 11 & 23 & $* *$ \\
\hline Brachypodium sylvaticum $^{\mathrm{sb}}$ & 1 & 0 & n.s. & Lapsana communis & 6 & 0 & $*$ \\
\hline Bromus ramosus & 6 & 0 & $*$ & Luzula pilosa ${ }^{\mathrm{sb}}$ & 1 & 7 & $*$ \\
\hline Campanula trachelium & 2 & 0 & n.s. & Mercurialis perennis & 18 & 12 & $*$ \\
\hline Carex pendula ${ }^{\mathrm{sb}}$ & 1 & 0 & n.s. & Milium effusum ${ }^{\mathrm{sb}}$ & 2 & 0 & n.s. \\
\hline Carex pilulifera & 0 & 6 & $*$ & Plantago major ${ }^{\mathrm{sb}}$ & 1 & 0 & n.s. \\
\hline Carex spicata & 5 & 0 & n.s. & Poa nemoralis & 17 & 5 & $* *$ \\
\hline Cephalantera damasonium & 3 & 0 & n.s. & Poa trivialis & 14 & 5 & $*$ \\
\hline Chenopodium polyspermum $^{\mathrm{sb}}$ & 2 & 0 & n.s. & Polygonum persicaria ${ }^{\mathrm{sb}}$ & 1 & 0 & n.s. \\
\hline Circaea lutetiana & 24 & 17 & $*$ & Primula elatior & 4 & 0 & n.s. \\
\hline Euonymus europaeus & 5 & 0 & n.s. & Stachys sylvatica & 9 & 2 & $*$ \\
\hline Euphorbia amygdaloides & 22 & 13 & $* *$ & Urtica dioica & 20 & 4 & $* * *$ \\
\hline Euphorbia amygdaloides ${ }^{\mathrm{sb}}$ & 1 & 0 & n.s. & Urtica dioica $^{\mathrm{sb}}$ & 17 & 3 & $* * *$ \\
\hline Fraxinus excelsior & 19 & 10 & $* *$ & Verbascum thapsus ${ }^{\mathrm{sb}}$ & 4 & 0 & n.s. \\
\hline Galium odoratum & 22 & 15 & $*$ & Veronica montana ${ }^{\mathrm{sb}}$ & 1 & 0 & n.s. \\
\hline Geranium robertianum & 17 & 6 & $* *$ & Viburnum opulus & 3 & 0 & n.s. \\
\hline Geum urbanum & 18 & 8 & $* *$ & Vicia sepium & 16 & 6 & $*$ \\
\hline Glechoma hederacea & 18 & 5 & $* * *$ & Vincetoxicum hirundaria & 2 & 0 & n.s. \\
\hline
\end{tabular}

Significant differences observed by a McNemar test

$* 0.01<P \leq 0.05$; ** $0.001<P \leq 0.01$; *** $P \leq 0.001$; n.s. not significant

sb Plants retrieved from the seed bank; Plant nomenclature follows Lambinon et al. (1998)

\section{Seed bank}

In the entire germination trial, a total of 3,402 seeds (63 species) germinated, of which 886 seeds (52 species) were from the Gallo-Roman sites and 2,516 (36 species) from the unoccupied sites. Nine seedlings $(0.26 \%)$ died before they could be identified. Mean seed density over all plots attained 7,875 seeds $\mathrm{m}^{-2}$ (ranging from 111 to 54,333 seeds $\mathrm{m}^{-2}$ ). GalloRoman sites yielded 4,101 seeds $\mathrm{m}^{-2}$ (333-23,444 seeds $\mathrm{m}^{-2}$ ), against 11,648 seeds $\mathrm{m}^{-2}(111-54,333$ seeds $\mathrm{m}^{-2}$ ) for the unoccupied sites.

Significant differences were found between the seed banks of the two site types for most variables (Table 2). Both total seed density and Je seed density were significantly higher on unoccupied sites, while the seed density without $J e$ was significantly higher on Gallo-Roman sites. Total species richness in the seed bank was significantly higher on Gallo-Roman sites, as was the Shannon-Wiener diversity index. For the CSR plant strategies, seed bank species of the unoccupied sites were more stress-tolerant than those from the Gallo-Roman sites. The latter had a significantly more competitive character while seed banks on both site types had a similar ruderal signature. Intra-type $\beta$-diversity was significantly lower on the Gallo-Roman sites. Several plant species displayed a preferential behavior towards a site type: two species appeared significantly more in the GalloRoman seed banks (Glechoma hederacea and Urtica dioica), while Luzula pilosa and Je were more present on unoccupied sites (Table 3).

Relationship between the vegetation and seed bank

Finally, total median community species richness (seed bank and vegetation) was significantly larger 
on Gallo-Roman sites (median: 34.0 (18-47); unoccupied sites: 23.5 (10-35); $\mathrm{Z}=-4.398 ; P \leq 0.001)$. As in many forest seed bank studies, the large discrepancy between seed bank and vegetation was confirmed (e.g. Thompson and Grime 1979; Fig. 2). Over all plots, 29 species occurred in both the seed bank and vegetation, compared to 34 which were restricted to the seed bank. Likewise, 92 species were confined to the vegetation. For the Gallo-Roman sites, 25 species occurred in both the vegetation and the seed bank, as opposed to 28 species which were confined to the seed bank. Unoccupied sites had only 15 species in common, with 22 species that were present only in the seed bank. These results are summarized by the median plot Raup and Crick dissimilarity index, which did not differ significantly $(\mathrm{Z}=-1.12 ; P>0.05)$ between the Gallo-Roman sites (median: 0.91) and the unoccupied sites (median: 1.00).

Interaction between soil type and former land use

A significant negative Spearman rank correlation $\left(r_{\mathrm{s}}=-0.70, P \leq 0.001\right)$ was found between unoccupied site $\mathrm{pH}$ and within-pair difference in $\mathrm{pH}$. A similar trend was observed for the within-pair differences in vegetation species richness, though only marginally significant $\left(r_{\mathrm{s}}=-0.39, P=0.06\right)$. No significant correlation with unoccupied site $\mathrm{pH}$ was observed for within-pair differences in total $\mathrm{P} \quad\left(r_{\mathrm{s}}=0.17\right.$, $P>0.05)$, seed bank species richness $\left(r_{\mathrm{s}}=-0.03\right.$, $P>0.05)$ and seed density $\left(r_{\mathrm{s}}=-0.11, P>0.05\right)$.

\section{Discussion}

Former Gallo-Roman occupation has led to significant geochemical alterations on the occupied sites as already indicated by Dupouey et al. (2002) and Dambrine et al. (2007). Verheyen et al. (1999) also found significant modifications of the chemical soil environment on a similar timescale, although considering only agriculture, not occupation. Here, the weathering of the calcareous sandstone, used as construction material, continually provides the soil with fresh nutrients, keeping $\mathrm{pH}$ at an elevated level as equally suggested by Dambrine et al. (2007). In addition, it should be noted that the $\mathrm{pH}$-modification is soil type dependent. The land use effect on soil $\mathrm{pH}$ is thus determined by the original soil conditions, i.e. the more acidic the initial soil conditions, the more pronounced the decrease in soil acidity. This interaction was not established for total $\mathrm{P}$ content, indicating that the elevation of total $\mathrm{P}$ was similar on all sites and thus probably land use induced. Elevated P levels are frequently reported by other authors in land use history studies on relatively short timescales (Koerner et al. 1997; Honnay et al. 1999; Compton and Boone 2000). However, soil P content is an equally good indicator for ancient land use (see Sandor and Eash 1995; Leonardi et al. 1999; Verheyen et al. 1999; Dupouey et al. 2002; Dambrine et al. 2007). The tight containment of $P$ in the vegetation-litter-soil cycle of forests (Wood et al. 1984) is presumably accountable for maintaining $P$ at such a high level. The elevated $\mathrm{P}$ content is probably explained by the addition of the calcareous sandstone and/or by fertility transfers from household waste and/or ash accumulation (Dupouey et al. 2002; Dambrine et al. 2007) and manuring (Sandor and Eash 1995; Compton and Boone 2000; Dupouey et al. 2002; Dambrine et al. 2007). However, an increase in soil organic carbon would then be equally expected despite the 1,600-year-long period (e.g. Mclauchlan 2006, Dambrine et al. 2007), but this was not the case. Yet, Koerner et al. (1997) and Compton and Boone (2000) point out that deeper soil layers $(15-30 \mathrm{~cm})$ have to be sampled to investigate soil C content. Surplus C may have leached to deeper soil horizons in the sandy soils, compared to the shallow leptosols in Thuilly-aux-Groseilles (Dupouey et al. 2002), where $C$ is unable to leach. This may explain why $\mathrm{P}$ is higher through e.g. manuring or waste accumulation but why no differences in $\mathrm{C}$ were observed.

Geochemical alterations are reflected in the herbaceous vegetation, as indicated by the EIV for soil acidity, fertility and moisture. Furthermore, occupied sites had increased species richness, as shown on similar timescales by Decocq et al. (2002), Dupouey et al. (2002) and Dambrine et al. (2007). Moreover, similar to the interaction between past land use and soil $\mathrm{pH}$, the increase in species richness had a tendency to be less expressed on initially rich soils compared to acid soils. This trend was to be expected, given the right-skewed unimodal relationship between $\mathrm{pH}$ (aluminium buffer range through $\mathrm{CaCO}_{3}$ buffer range) and forest plant species richness (Watkinson et al. 2001), which illustrates that the 

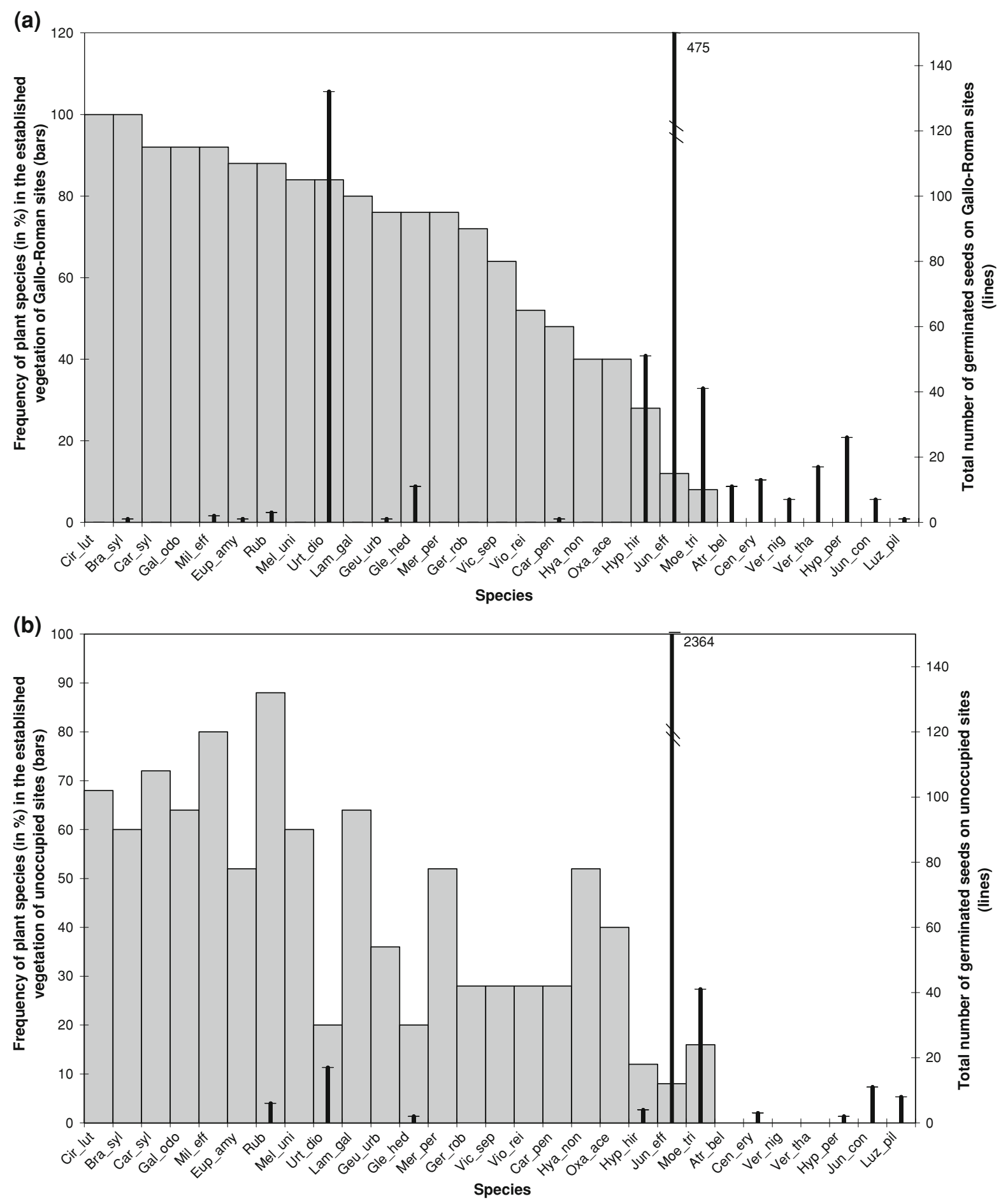

Fig. 2 The frequency of occurrence of species as established plants (histograms) and the total number of germinated seeds in the persistent soil seed bank (vertical bars) on (a) GalloRoman sites and (b) Unoccupied sites. Histograms present species of the vegetation which occur at least in $25 \%$ of the plots on both site types complemented with important seed bank species. Full species names can be found in Appendix Table 1 
increase in species richness with increasing soil $\mathrm{pH}$ is indeed dependent on initial soil $\mathrm{pH}$.

Nevertheless, the competitive character of the vegetation (Table 2) suggests that vegetation of the occupied sites more closely resembles the herb layer of recent forest (see Bossuyt and Hermy 2000). Indeed, several competitive, nitrophileous species (e.g. Urtica dioica, Stachys sylvatica) and fastcolonizing species like e.g. Geum urbanum, Circaea lutetiana and Glechoma hederacea occur significantly more on the Gallo-Roman sites (Table 3). However, several ancient-forest species (sensu Hermy et al. 1999) are found significantly more (e.g. Brachypodium sylvaticum, Euphorbia amygdaloides, Mercurialis perennis, Poa nemoralis, Viola reichenbachiana) or only occur (e.g. Primula elatior, Campanula trachelium, Euonymus europaeus) on Gallo-Roman sites (Table 3). Sixteen hundred years of forest cover since the cessation of occupation has probably caused dispersal limitation, an important factor known to inhibit colonization of ancient forest species (Bossuyt et al. 1999; Honnay et al. 1999; Verheyen and Hermy 2001), to be overcome. Some ancient forest species even find more suitable moisture and fertility conditions on the former occupied sites, compared to the acid and nutrientpoor conditions on the unoccupied sites (Tables 1 and 2). Although several ancient forest species fail to recruit in secondary forests because of low habitat quality (Verheyen and Hermy 2001), this seems improbable as species of this group are found significantly more (e.g. Arum maculatum) or are restricted (e.g. Primula elatior) to the Gallo-Roman sites.

Moreover, several calciphileous species, e.g. Cephalantera damasonium, Vincetoxicum hirundaria, Viburnum opulus and Carex spicata (according to Rameau et al. 1989), are completely absent on the unoccupied sites (Table 3). Possible explanations for their presence are direct introduction by Gallo-Romans (e.g. Vincetoxicum hirundaria known for its medicinal use in Roman times) or long-distance dispersal events (Cain et al. 1998) from the calcareous ravines in Compiègne (Tombal 1972). As Gallo-Roman sites contain many forest species with high conservation value, the latter may be considered as "islands" of high biodiversity in an otherwise acid forest matrix (cf. patterns observed by Dambrine et al. 2007). This is of particular interest, since many previous land use impact studies (e.g. Peterken and Game 1984) prove former (recent) land use to be a factor which negatively affects biodiversity in recent forests.

However, although the 24 spatially isolated GalloRoman sites support a rich and neutrophileous vegetation, intra-type $\beta$-diversity is reduced (Table 2). The biotic homogenization effect of former land use (Vellend et al. 2007) still affects the vegetation composition at present, as it remains homogenized. However, the explanatory mechanisms of dispersal limitation and reduced landscape variability (Vellend et al. 2007) are not valid here, as dispersal limitation is overcome (cf. higher) and landscape variability is enhanced by the presence of the Gallo-Roman settlements. Rather, Fraterrigo et al. (2006) suggest that nutrient availability may play a vital role in determining variability of herbaceous plant abundance in human altered forests. Thus, the large and broad range of all soil variables on the unoccupied sites [larger than ranges on the Gallo-Roman sites (Table 1)] combined with a higher coefficient of variation (Table 1) suggests the strong heterogeneous character of soil characteristics on the unoccupied sites opposite to the Gallo-Roman sites. As such, acidophileous and some more nutrientdemanding species can find a suitable habitat on the former site type, though not likely within one site. Consequently, intra-type $\beta$-diversity of the vegetation on the unoccupied sites is increased.

The soil seed bank on Gallo-Roman sites does not resemble that of the unoccupied sites, not in seed densities, species richness (Table 2) nor in species composition (Table 3; Fig. 1). The increased Juncus effusus density in the seed bank is interpreted as a probable consequence of habitat suitability rather than forest management, as sites were chosen to have a similar silvicultural history. Juncus effusus is not strictly calcifuge, but it is much less common on basic soils (Richards and Clapham 1941). Hence the behaviour of the species observed in this particular study.

As vegetation differs, one might interpret the differences in seed bank composition as trivial. However, mostly species others than those in the vegetation cause the difference in seed bank composition, as indicated by the large discrepancy between seed bank and vegetation (Fig. 1). Furthermore, as 
within-pair seed bank differences are not dependent on the initial soil type but vegetation differences tend to be (cf. above), this corroborates the hypothesis that the observed overall seed bank differences are at least in part unrelated to overall vegetation differences. The vegetation is nonetheless partially responsible for the observed differences in seed bank composition between site types. Several ancient forest species (e.g. Brachypodium sylvaticum, Carex pendula, Euphorbia amygdaloides, Festuca gigantea, Milium effusum, Veronica montana), characterized by low density persistent seed banks $\left(<50\right.$ seeds $\mathrm{m}^{-2}$; Bossuyt et al. 2002) are confined to the seed banks on Gallo-Roman sites. Their abundance in the vegetation of the Gallo-Roman sites probably explains why they are found in the soil seed bank.

However, the vegetation differences alone were not the main driving force behind the seed bank differences. The former occupation and consequent geochemical alteration also contribute to the present variation in seed bank composition. A direct influence of the Gallo-Roman occupation is ruled out, as seeds have never been reported to remain viable in the soil for 1,600 years. However, ruderal species of human agricultural environments may have been introduced by the occupation (e.g. Plantago major, Polygonum persicaria, Chenopodium spp., Verbascum thapsus), together with species like Atropa bella-donna, which had known medicinal uses. Yet, despite the suitable geochemical environment, these species all need a specific disturbance regime for their long-term survival. The forest managementcoppice and coppice-with-standards - provided a disturbance regime with recurring light phases [every 15-30 years (Lanier et al. 1986)] enabling these species to reproduce, incorporate seeds in the soil and persist in the seed bank until today. As ruderal species are known for their high persistence (Thompson et al. 1998), periods of 30 years until the next disturbance pose no significant problem for their survival. This way, their seeds increased both species richness and seed density on the Gallo-Roman sites. Moreover, compositional homogeneity between the Gallo-Roman seed banks was increased (low intratype $\beta$-diversity, Table 2 ). The explanatory mechanism is probably similar to the one of the vegetation, as the seed bank is in fact the post-clearcut vegetation. The homogenized soil characteristics on the Gallo-Roman sites make them all a suitable habitat for some neutrophileous seed bank species (e.g. Verbascum thapsus, Urtica dioica, Atropa belladonna) opposite to only some sites on the reference sites. The natural seed bank heterogeneity of all sites-a consequence of heterogeneous canopy dynamics in time and space (Runkle 1985)—is superimposed with these species on the Gallo-Roman sites, consequently homogenizing the seed banks on the latter.

Summarizing, severe geochemical alterations favoured a forest habitat which, in combination with a 1,600-year period of continuous forest cover, allows ancient forest species, calciphileous specialist species and more competitive fast-colonizing species to co-exist, increasing $\alpha$-biodiversity, but lowering $\beta$-similarity (Table 2) between Gallo-Roman sites. As for the soil seed bank, the land use itself introduced persistent ruderal species mainly of human agricultural environments, while several ancient forest species formed a persistent seed bank due to their increased abundance on the occupied sites, resulting in higher species richness, seed density and a lower $\beta$-similarity (Table 2) among the seed banks of Gallo-Roman sites. The forest management probably enabled these ruderal species to persist until today.

Given the extent of the former Gallo-Roman land use in Europe, sites under forest formerly used by Romans are certainly not a rare feature. Therefore, the impact of ancient land use on forest vegetation in Europe cannot and must not be underestimated (cf. Dambrine et al. 2007). These findings equally indicate the importance of considering long-term studies in biodiversity conservation (Willis and Birks 2006) and the need to extend the temporal scale of land use impact studies beyond the limits of traditional cartographic or archival sources (e.g. Briggs et al. 2006).

Acknowledgements J.P. would like to thank Eric van Beek for the help provided with the seed bank experiment. The authors thank Stéphanie Renaux for her contribution to field work and preliminary data analysis and the French 'Office National des Forêts' for having facilitated our field work and provided useful information about abiotic conditions and management. 


\section{Appendices}

Table 1 Frequency of occurrence of each plant species in the vegetation/seed bank and significance of difference between GalloRoman and unoccupied sites (McNemar test)

\begin{tabular}{|c|c|c|c|c|c|}
\hline \multicolumn{2}{|l|}{ Plant species } & \multirow{2}{*}{$\begin{array}{l}\begin{array}{l}\text { Gallo-R } \\
(n=24)\end{array} \\
11\end{array}$} & \multirow{2}{*}{$\begin{array}{l}\text { UnOc. } \\
(n=24)\end{array}$} & \multirow{2}{*}{$\begin{array}{l}\text { Sign. } \\
\text { n.s. }\end{array}$} & \multirow{2}{*}{$\begin{array}{l}\begin{array}{l}\text { Shade } \\
\text { index }\end{array} \\
4\end{array}$} \\
\hline Acer campestre $\mathrm{L}$. & & & & & \\
\hline Acer platanoides $\mathrm{L}$. & & 2 & 1 & n.s. & 5 \\
\hline Acer pseudoplatanus L. & & 7 & 7 & n.s. & 5 \\
\hline Ajuga reptans $\mathrm{L}$. & & 7 & 2 & n.s. & \\
\hline Alliaria petiolata (Bieb.) Cavara et Grande & & 13 & 3 & $* *$ & \\
\hline Anemone nemorosa $\mathrm{L}$. & & 4 & 9 & n.s. & \\
\hline Arum maculatum L. & & 13 & 5 & $* *$ & \\
\hline Athyrium felix-femina (L.) Roth & & 10 & 6 & n.s. & \\
\hline Atropa bella-donna L. ${ }^{\mathrm{sb}}$ & Atr_bel & 4 & 0 & n.s. & \\
\hline Brachypodium sylvaticum (Huds.) Beauv. & Bra_syl & 24 & 14 & $* *$ & \\
\hline Bromus ramosus Huds. & & 6 & 0 & $*$ & \\
\hline Cardamine impatiens L. & & 5 & 3 & n.s. & \\
\hline Carex pendula Huds. & Car_pen & 12 & 6 & n.s. & \\
\hline Carex pilulifera $\mathrm{L}$. & & 0 & 6 & $*$ & \\
\hline Carex remota Jusl. Ex L. & & 9 & 5 & n.s. & \\
\hline Carex spicata Huds. & & 5 & 0 & n.s. & \\
\hline Carex sylvatica Huds. & Car_syl & 22 & 17 & n.s. & \\
\hline Carpinus betulus L. & & 18 & 11 & n.s. & 6 \\
\hline Centaurium erythraea Rafn $^{\mathrm{sb}}$ & Cen_ery & 5 & 2 & n.s. & \\
\hline Circaea lutetiana $\mathrm{L}$. & Cir_lut & 24 & 17 & $*$ & \\
\hline Clematis vitalba $\mathrm{L}$. & & 4 & 1 & n.s. & \\
\hline Convallaria majalis $\mathrm{L}$. & & 3 & 4 & n.s. & \\
\hline Cornus sanguinea & & 2 & 1 & n.s. & 3 \\
\hline Corylus avellana & & 1 & 1 & n.s. & 4 \\
\hline Crataegus monogyna Jacq. & & 7 & 4 & n.s. & \\
\hline Deschampsia cespitosa (L.) Beauv. & & 9 & 5 & n.s. & \\
\hline Dryopteris carthusiana (Vill.) H.P. Fuchs & & 6 & 12 & n.s. & \\
\hline Dryopteris filix-mas (L.) Schott & & 18 & 14 & n.s. & \\
\hline Epilobium sp. ${ }^{\mathrm{sb}}$ & & 5 & 1 & n.s. & \\
\hline Euonymus europaeus L. & & 5 & 0 & n.s. & \\
\hline Euphorbia amygdaloides L. & Eup_amy & 22 & 13 & $* *$ & \\
\hline Fagus sylvatica $\mathrm{L}$. & & 7 & 12 & n.s. & 6 \\
\hline Festuca gigantea (L.) Vill. & & 8 & 4 & n.s. & \\
\hline Festuca heterophylla Lam. & & 4 & 4 & n.s. & \\
\hline Fraxinus excelsior $\mathrm{L}$. & & 19 & 10 & $* *$ & 4 \\
\hline Galeopsis tetrahit $\mathrm{L}$. & & 2 & 3 & n.s. & \\
\hline Galium aparine $\mathrm{L}$. & & 5 & 1 & n.s. & \\
\hline Galium odoratum (L.) Scop. & Gal_odo & 22 & 15 & $*$ & \\
\hline Geranium robertianum L. & Ger_rob & 17 & 6 & $* *$ & \\
\hline Geum urbanum L. & Geu_urb & 18 & 8 & $* *$ & \\
\hline Glechoma hederacea L. & Gle_hed & 18 & 5 & $* * *$ & \\
\hline Glechoma hederacea L. $^{\text {sb }}$ & & 7 & 1 & $*$ & \\
\hline
\end{tabular}


Table 1 continued

\begin{tabular}{|c|c|c|c|c|c|}
\hline Plant species & & $\begin{array}{l}\text { Gallo-R } \\
(n=24)\end{array}$ & $\begin{array}{l}\text { UnOc. } \\
(n=24)\end{array}$ & Sign. & $\begin{array}{l}\text { Shade } \\
\text { index }\end{array}$ \\
\hline Hedera helix $\mathrm{L}$. & & 21 & 22 & n.s. & \\
\hline Holcus mollis L. & & 4 & 7 & n.s. & \\
\hline Hyacinthoides non-scripta (L.) Chouard ex Rothm. & Hya_non & 10 & 13 & n.s. & \\
\hline Hypericum hirsutum $\mathrm{L}$. & & 7 & 3 & n.s. & \\
\hline Hypericum hirsutum L. ${ }^{\text {sb }}$ & Hyp_hir & 8 & 2 & n.s. & \\
\hline Hypericum perforatum $\mathrm{L}^{\mathrm{sb}}$ & Hyp_per & 9 & 2 & n.s. & \\
\hline Juncus conglomeratus L. ${ }^{\text {sb }}$ & Jun_con & 5 & 4 & n.s. & \\
\hline Juncus effusus L. & & 3 & 2 & n.s. & \\
\hline Juncus effusus L. ${ }^{\text {sb }}$ & Jun_eff & 11 & 23 & $* *$ & \\
\hline Lamium galeobdolon (L.) L. & Lam_gal & 19 & 15 & n.s. & \\
\hline Lapsana communis $\mathrm{L}$. & & 6 & 0 & $*$ & \\
\hline Ligustrum vulgare L. & & 4 & 2 & n.s. & \\
\hline Lonicera periclymenum $\mathrm{L}$. & & 9 & 13 & n.s. & \\
\hline Luzula pilosa (L.) Willd. ${ }^{\mathrm{sb}}$ & Luz_pil & 1 & 7 & $*$ & \\
\hline Melica uniflora Retz. & Mel_uni & 20 & 14 & n.s. & \\
\hline Mercurialis perennis $\mathrm{L}$. & Mer_per & 18 & 12 & $*$ & \\
\hline Milium effusum L. & Mil_eff & 22 & 19 & n.s. & \\
\hline Moehryngia trinervia (L.) Clairv. & & 2 & 4 & n.s. & \\
\hline Moehryngia trinervia (L.) Clairv. ${ }^{\mathrm{sb}}$ & Moe_tri & 14 & 10 & n.s. & \\
\hline Mycelis muralis (L.) Dum. & & 3 & 3 & n.s. & \\
\hline Oxalis acetosella $\mathrm{L}$. & Oxa_ace & 10 & 10 & n.s. & \\
\hline Paris quadrifolia L. & & 5 & 2 & n.s. & \\
\hline Poa nemoralis L. & & 17 & 5 & $* *$ & \\
\hline Poa trivialis $\mathrm{L}$. & & 14 & 5 & $*$ & \\
\hline Polygonatum multiflorum (L.) All. & & 10 & 6 & n.s. & \\
\hline Potentilla sterilis (L.) Garcke & & 3 & 2 & n.s. & \\
\hline Prunus avium (L.) L. & & 2 & 5 & n.s. & 4 \\
\hline Prunus serotina Ehrh. & & 3 & 8 & n.s. & \\
\hline Pteridium aquilinum (L.) Kuhn. & & 11 & 10 & n.s. & \\
\hline Quercus petraea & & 0 & 0 & n.s. & 4 \\
\hline Quercus robur & & 0 & 2 & n.s. & 3 \\
\hline Quercus spp. seedlings & & 12 & 11 & n.s. & \\
\hline Rosa arvensis Huds. & & 6 & 2 & n.s. & \\
\hline Rubus fructicosus aggr. & & 21 & 21 & n.s. & \\
\hline Rubus spp. ${ }^{\text {sb }}$ & Rub & 3 & 5 & n.s. & \\
\hline Sambucus nigra & & 2 & 1 & n.s. & 4 \\
\hline Scrophularia nodosa $\mathrm{L}$. & & 7 & 2 & n.s. & \\
\hline Scrophularia nodosa L. ${ }^{\text {sb }}$ & & 7 & 7 & n.s. & \\
\hline Sorbus aucuparia & & 1 & 3 & n.s. & 3 \\
\hline Stachys sylvatica $\mathrm{L}$. & & 9 & 2 & $*$ & \\
\hline Stellaria holostea L. & & 7 & 5 & n.s. & \\
\hline Tilia cordata & & 1 & 0 & n.s. & 5 \\
\hline Ulmus minor & & 1 & 0 & n.s. & 4 \\
\hline Urtica dioica $\mathrm{L}$. & & 20 & 4 & $* * *$ & \\
\hline
\end{tabular}


Table 1 continued

\begin{tabular}{|c|c|c|c|c|c|}
\hline Plant species & & $\begin{array}{l}\text { Gallo-R } \\
(n=24)\end{array}$ & $\begin{array}{l}\text { UnOc. } \\
(n=24)\end{array}$ & Sign. & $\begin{array}{l}\text { Shade } \\
\text { index }\end{array}$ \\
\hline Urtica dioica $\mathrm{L}^{\mathrm{sb}}$ & Urt_dio & 17 & 3 & $* * *$ & \\
\hline Verbascum nigrum L. ${ }^{\text {sb }}$ & Ver_nig & 1 & 0 & n.s. & \\
\hline Verbascum thapsus L. ${ }^{\mathrm{sb}}$ & Ver_tha & 4 & 0 & n.s. & \\
\hline Veronica montana L. & & 6 & 4 & n.s. & \\
\hline Veronica officinalis L. ${ }^{\text {sb }}$ & & 1 & 5 & n.s. & \\
\hline Vicia sepium $\mathrm{L}$. & Vic_sep & 16 & 6 & $*$ & \\
\hline Viola reichenbachiana Jord. Ex Boreau & Vio_rei & 13 & 7 & $*$ & \\
\hline
\end{tabular}

Herbaceous plant species with a frequency larger than five are represented in the table. Important seed bank species with a lower frequency are also present in the table. Tree species used to calculate cover of light-shade and deep-shade casting species per strata are also represented (frequencies in herbaceous layer) together with their Shade Casting Index (Ellenberg 1996). Remaining species are represented below the table as follows: "Species name: frequency on Gallo-Roman sites, frequency on unoccupied sites". Species abbreviations of those plants species used to construct Fig. 1 are also presented. Plant nomenclature follows Lambinon et al. (1998).

Shade index: ranges from 1 (very limited shade) to 6 (deep shade); Gallo-R, Gallo-Roman; UnOc., unoccupied site; ${ }^{\text {sb }}$ Seed bank; $* 0.01<P \leq 0.05 ; * * 0.001<P \leq 0.01$; *** $P \leq 0.001$; n.s., not significant

Vegetation

Agrostis canina L.: 1, 0; Agrostis stolonifera L.: 0, 1; Allium ursinum L.: 1, 0; Calamagrostis epigejos (L.) Roth: 3, 1; Campanula trachelium L.: 2, 0; Carex elata All.: 1, 0; Cardamine flexuosa With: 1, 0: Cardamine pratensis L.: 1, 1; Carex depauperata Curt. Ex With.: 1, 0; Carex flacca Schreb.: 1, 1; Carex strigosa Huds.: 0, 2; Cephalantera damasonium (Mill.) Druce: 3, 0; Chaerophyllum temulum L.: 1, 0; Chelidonium majus L.: 2, 0; Chrysosplenium oppostifolium L.: 1, 0; Cornus mas L.: 0, 1; Crataegus laevigata (Poiret) DC.: 0, 2; Dactylis glomerata L.: 1, 0; Deschampsia flexuosa (L.) Trin.: 0, 3; Dryopteris dilatata (Hoffman) A. Gray: 1, 1; Elymus caninus (L.) L.: 1, 1; Epilobium montanum L.: 2, 0; Epilobium hirsutum L.: 2, 1; Epilobium roseum Schreb.: 1, 0; Equisetum sp.: 1, 0; Festuca sp.: 0, 1; Fragaria vesca L.: 2, 1; Heracleum sphondylium L.: 1, 0; Holcus lanatus L.: 0, 1; Hypericum tetrapterum Fries: 1, 0; Ilex aquifolium L.: 0, 4; Impatiens noli-tangere L.: 1, 0; Iris pseudacorus L.: 1, 0; Luzula forsteri Smith DC.: 0, 2; Maianthemum bifolium (L.) F.W. Schmidt: 1, 0; Melampyrum pratense L.: 1, 2; Molinea caerula (L.) Moench: 0, 2; Polystichum setiferum (Frossk.) Woynar: 1, 1; Primula elatior (L.) Hill: 4, 0; Prunus spinosa L.: 1, 0; Ranunculus auricomus L.: 2, 2; Ranunculus repens L.: 1, 0; Ribes uva-crispa L.: 2, 1; Ribes rubrum L.: 1, 0; Rubus idaeus L.: 1, 1; Rumex sanguineus L.: 1, 0; Rumex obtusifolius L.: 4, 0; Ruscus aculeatus L.: 1, 2; Teucrium scorodonia L.: 1, 2; Torilis japonica (Houtt.) DC.: 1, 0; Veronica sp.: 1, 0; Veronica chamaedrys L.: 1, 0; Viburnum opulus L.; 3, 0; Vincetoxicum hirundaria Med.: 2, 0; Viola odorata L.: 1, 0; Viola riviniana Reichenb.: 1, 2

Seed bank

Agrostis capillaris L.: 0, 1; Agrostis stolonifera L.: 0, 1; Ajuga reptans L.: 0, 1; Atropa bella-donna L.: 4, 0; Brachypodium sylvaticum (Huds.) Beauv.: 1, 0; Cardamine impatiens L.: 3, 0; Cardamine sp.: 4, 0; Carex pendula Huds.: 1, 0; Carex pilulifera L.: 1, 2; Carex remota Jusl. Ex L.: 1, 1; Chaerophyllum temulum L.: 2, 0; Chenopodium album L.: 1, 0; Chenopodium polyspermum L.: 2, 0; Conyza canadensis (L.) Cronq.: 3,1; Cytisus scoparius (L.) Link.: 1, 3; Deschampsia cespitosa (L.) Beauv.: 0, 1; Epilobium ciliatum Rafin.: 3, 0; Epilobium lanceolatum Seb. Et Mauri: 3, 1; Euphorbia amygdaloides L. 1, 0; Festuca gigantea (L.) Vill.: 1, 0; Geum urbanum L.: 1, 0; Hypericum dubium Leers: 0, 1; Hypericum humifusum L.: 1, 1; Hypericum pulchrum L.: 0, 1; Hypericum tetrapterum Fries: 0, 1; Juncus articulatus L.: 1, 2; Juncus bulbosus L.: 1, 0; Lapsana communis L.: 1, 0; Milium effusum L.: 2, 0; Plantago major L.: 1, 0; Poa nemoralis L.: 0, 1; Poa pratensis L.: 1, 1; Poa trivialis L.: 4, 0; Polygonum persicaria L.: 1, 0; Potentilla reptans L.: 0, 1; Potentilla sterilis (L.) 
Garcke: 1, 2; Ranunculus repens L.: 1, 0; Rumex obtusifolius L.: 1, 0; Sagina procumbens L.: 1, 1; Senecio jacobea L.: 1, 0; Solanum nigrum L.: 1, 1; Sonchus arvensis L.: 1, 0; Sonchus asper (L.) Hill: 0, 1; Stachys sylvatica L.: 1, 1; Teucrium scorodonia L.: 1, 0; Veronica montana L.: 1,0

\section{References}

Anne P (1945) Sur le dosage rapide du carbone organique de sols. Annales Agronomiques 15:161-172 (in French)

Aubert G (1978) Méthodes d' analyse des sols. Edition C.R.D.P., Marseille (in French)

Bellemare J, Motzkin G, Foster DR (2002) Legacies of the agricultural past in the forested present: an assessment of historical land use effects on rich mesic forests. J Biogeogr 29:1401-1420

Bigwood DW, Inouye DW (1988) Spatial pattern analysis of seed banks: an improved method and optimized sampling. Ecology 69:497-507

Bossuyt B, Hermy M (2000) Restoration of the understorey layer of recent forest bordering ancient forest. Appl Veg Sci 3:43-50

Bossuyt B, Hermy M (2001) Influence of land use history on seed banks in European temperate forest ecosystems: a review. Ecography 24:225-238

Bossuyt B, Hermy M, Deckers J (1999) Migration of herbaceous plant species across ancient-recent forest ecotones in central Belgium. J Ecol 87:628-638

Bossuyt B, Heyn M, Hermy M (2002) Seed bank and vegetation composition of forest stands of varying age in central Belgium: consequences for regeneration of ancient forest vegetation. Plant Ecol 162:33-48

Bray RH, Kurtz LT (1945) Determination of total, organic and available forms of phosphorus in soils. Soil Sci 59:39-45

Briggs JM, Spielmann KA, Schaafsma H et al (2006) Why ecology needs archaeologists and archaeology needs ecologists. Front Ecol Environ 4(4):180-188

Bürgi M, Gimmi U (2007) Three objectives of historical ecology: the case of litter collecting in Central Europena forests. Landsc Ecol 22:77-87

Cain ML, Damman H, Muir A (1998) Seed dispersal and the Holocene migration of woodland herbs. Ecol Monogr 68:325-347

Compton JE, Boone RD (2000) Long-term impacts of agriculture on soil carbon and nitrogen in New England forests. Ecology 81:2314-2330

Dambrine E, Dupouey J-L, Laüt L et al (2007) Present forest biodiversity patterns in France related to former Roman agriculture. Ecology 88:1430-1439

Decocq G, Vieille V, Racinet P (2002) Influence des facteurs historiques sur la végétation actuelle: le cas des mottes castrales en milieu forestier (Picardie, France). Acta Bot Gall 149:197-215 (in French)

Doyen B, Thuillier P, Decocq G (2004) Archéologie des milieux boisés en Picardie. Revue Archéologique de Picardie 1/2:149-164 (in French)
Dupouey J-L, Dambrine E, Lafitte JD et al (2002) Irreversible impact of past land use on forest soils and biodiversity. Ecology 83:2978-2984

Ellenberg H (1996) Vegetation Mitteleuropas mit den Alpen in ökologischer, dynamischer und historischer Sicht. Ulmer, Stuttgart (in German)

Ellenberg H, Weber HE, Ruprcht D et al (1992) Zeigerwerte von pflanzen in Mitteleuropa. Scr Geobot 18:1-258 (in German)

Flinn KM, Vellend M (2005) Recovery of forest plant communities in post-agricultural landscapes. Front Ecol Environ 3:243-250

Flinn KM, Vellend M, Marks PL (2005) Environmental causes and consequences of forest clearance and agricultural abandonment in central New York, USA. J Biogeogr 32:439-452

Fraterrigo JM, Turner MG, Pearson SM (2006) Interactions between past land use, life-history traits and understory spatial heterogeneity. Landsc Ecol 21:777-790

Graae BJ, Sunde PB, Fritzborger B (2003) Vegetation and soil differences in ancient opposed to new forests. For Ecol Manage 117:179-190

Harrelson SM, Matlack GR (2006) Influence of stand age and physical environment on the herb composition of secondgrowth forest, Strouds Run, Ohio, USA. J Biogeogr 33:1139-1149

Hermy M, Honnay O, Firbank L et al (1999) An ecological comparison between ancient and other forest plant species of Europe, and the implications for forest conservation. Biol Conserv 91:9-22

Honnay O, Hermy M, Coppin P (1999) Impact of habitat quality on forest plant species colonization. For Ecol Manage 115:157-170

Hunt R, Hogdson JH, Thompson K et al (2004) A new practical tool for deriving a functional signature for herbaceous vegetation. Appl Veg Sci 7:163-170

Kent M, Coker P (1992) Vegetation description and analysis. A practical approach. Wiley, Chichester

Koerner W, Dupouey J-L, Dambrine E et al (1997) Influence of past land-use on the vegetation and soils of present day forest in the Vosges mountains, France. J Ecol 85:351-358

Lambinon J, De Langhe J-E, Delvosalle L et al (1998) Flora van België, het Groothertogdom Luxemburg, NoordFrankrijk en de aangrenzende gebieden (Pteridofyten en Spermatofyten). Nationale plantentuin van België, Meise (in Dutch)

Lanier L, Badré M, Delabraze P et al (1986) Précis de sylviculture. ENGREF, Nancy (in French)

Leonardi G, Miglavacca M, Nardi S (1999) Soil phosphorus analysis as an integrative tool for recognizing buried ancient ploughsoils. J Archaeol Sci 26:343-352

Loeppert RH, Suarez DL (1996) Carbonate and gypsum. In: Bigham JM, Bartels JM (eds) Methods of soil analysis, third part, chemical methods. Soil Science Society of America, Madison, pp 437-474

McLauchlan K (2006) The nature and longevity of agricultural impacts on soil carbon and nutrients: a review. Ecosystems 9:1364-1382

Maussion A (2003) Occupation ancienne du sol et milieux forestiers actuels, en France métropolitaine. Synthèse bibliographique. INRA-Nancy, Champenoux (in French) 
O.N.F. (1995) Foret domaniale de Compiegne - Révision d' amenagement 1996-2010. Office National des Forets Direction Nationale de Picardie - Division de Compiegne, Compiègne (in French)

Pansu M, Gautheyrou J (2003) L'analyse du Sol Minéralogique, Organique et Minérale. Springer-Verlag, Paris (in French)

Peterken GF (1996) Natural woodland: ecology and conservation in Northern temperate regions. Cambridge University Press Inc., United Kingdom

Peterken GF, Game M (1984) Historical factors affecting the number and distribution of vascular plant species in the woodlands of central Lincolnshire. J Ecol 72:155-182

Pounds NJG (1973) An historical geography of Europe 450 B.C.-A.D. 1330. Cambridge University press Inc., United Kingdom

Rameau JC, Mansion D, Dumé G et al (1989) Flore Forestière Française, Guide Ecologique Illustré. 1. Plaines et Collines. Institut pour le développement forestier, Paris (in French)

Raup DM, Crick RE (1979) Measurement of faunal diversity in paleontology. J Paleontol 53:1213-1227

Runkle JR (1985) The disturbance regime in temperate forests. In: Pickett STA, White PS (eds) The ecology of natural disturbance and patch dynamics. Academic Press, London, pp 17-33

Richards PW, Clapham AR (1941) Juncus effusus L J Ecol 29:375-380

Sandor JA, Gersper PL, Hawley JW (1990) Prehistoric agricultural Terraces and soils in the Mimbres area, New Mexico. World Arch 22(1):70-86

Sandor JA, Eash NS (1995) Ancient agricultural soils in the Andes of Southern Peru. Soil Sci Soc Am J 59:170-179

Schulte LA, Mladenoff DJ, Crow TR et al (2007) Homogenization of Northern U.S. Great lakes forest due to human land use. Landsc Ecol 22:1089-1103

Siegel S, Castellan NJJ (1988) Nonparametric statistics for the behavioral sciences. McGraw-Hill book company, Singapore

SPSS (2003) SPSS Inc., Chicago

Ter Heerdt GNJ, Verweij GL, Bekker RM et al (1996) An improved method for seed-bank analysis: seedling emergence after removing the soil by sieving. Funct Ecol 10:144-151
Thompson K, Grime JP (1979) Seasonal variation in the seed banks of herbaceous species in ten contrasting habitats. J Ecol 67:893-921

Thompson K, Bakker JP, Bekker RM et al (1998) Ecological correlates of seed persistence in soil in the North-West European flora. J Ecol 86:163-169

Thuillier P (2004) La prospection en milieu boisé. In: Schwerdroffer J, Racinet P (eds) Méthodes et initiations d'histoire et d'archéologie. Editions du Temps, Nantes, pp 26-37 (in French)

Tombal P (1972) Etude phytocoenologique et esquisse macrobiocoenotique du proclimax forestier (Ilici-Fagetum) des Beaux-Monts de Compiègne (Oise-France). Bulletin de la société botanique du nord de la France 25:19-52 (in French)

Van der Maarel E (1979) Transformation of cover-abundance values in phytosociology and its effects on community similarity. Vegetatio 39:97-114

Vanwalleghem T, Verheyen K, Hermy M et al (2004) Legacies of Roman land-use in the present-day vegetation in Meerdaal Forest (Belgium)? Belg J Bot 137:181-187

Vellend M, Verheyen K, Flinn KM et al (2007) Homogenization of forest plant communities and weakening of species-environment relationships via agricultural land use. J Ecol 95:565-573

Verheyen K, Hermy M (2001) The relative importance of dispersal limitation of vascular plants in secondary forest succession in Muizen forest, Belgium. J Ecol 89:829-840

Verheyen K, Bossuyt B, Hermy M et al (1999) The land use history (1278-1990) of a mixed hardwood forest in western Belgium and its relationship with chemical soil characteristics. J Biogeogr 26:1115-1128

Watkinson AR, Riding AE, Cowie NR (2001) A community and population perspective of the possible role of grazing in determining the ground flora of ancient woodlands. Forestry 74:231-239

Willis KJ, Birks HJB (2006) What is natural? The need for a long-term perspective in biodiversity conservation. Science 314:1261-1265

Wood T, Bormann FH, Voigt GK (1984) Phosphorus cycling in a Northern Hardwood Forest: biological and chemical control. Science 223:391-393 